\title{
"COMO LA VIHUELA TEMPLADA, QUE HACE DULCE ARMONIA $»:$ IMAGEN DEL HOMBRE Y DE LA CIENCIA EN EL RENACIMIENTO DESDE UN RELATO DE PÉREZ DE OLIVA (1494-1531)
}

\author{
José Luis Fuertes Herreros \\ Universidad de Salamanca
}

\begin{abstract}
RESUMEN
Ante los cambios y los logros que la ciencia y la técnica están produciendo a finales del siglo XV y XVI, fragmentando el orden medieval, Fernán Pérez de Oliva, para concertar los nuevos tiempos, ofrecerá una nueva imagen del hombre. Éste deberá ser como la vihuela bien templada que produce dulce armonía.
\end{abstract}

Palabras clave: Filosofía, Ciencia, Arquitectura, Música, Hombre, Fortuna, Filosofía de la historia, Renacimiento, Fernán Pérez de Oliva, Erasmo de Rotterdam.

\begin{abstract}
In view of the changes and achievements which the science and technique are producing at the end of the XV and XVI centuries, fragmenting the medieval order, Fernán Pérez de Oliva, in order to bring into harmony the new Renaissance times, will offer a new image of the human being. This will must be as the well tuned vihuela wich produces sweet harmony.
\end{abstract}

Key words: Philosophy, Science, Architecture, Music, Human being, Fortune, Philosophy of history, Renaissance, Fernán Pérez de Oliva, Erasmus of Rotterdam.

\section{INTRODUCCIÓN}

Ante los cambios y logros que la ciencia y la técnica están produciendo a finales del siglo XV y comienzos del XVI, fragmentando el viejo orden medieval, aparece Fernán Pérez de Oliva, buscando un nuevo punto de ordenación y unificación. Esta nueva situación, vivida en el Renacimiento, y experimentada por Pérez de Oliva, obligará a éste a construir una nueva imagen del hombre, ensayando una nueva lectura y un nuevo relato sobre la creación del hombre y del mundo. El hombre aparecerá como principio de unificación. Será como la vihuela templada, que hace dulce armonía. Él llenará de sentido a todo lo creado, y se servirá de la ciencia y de la técnica para transformar este mundo en reino del hombre.

Es por ello, que quizá, Fernán Pérez de Oliva, sea uno de los autores que mejor encarna y proclama el espíritu de estos nuevos tiempos. Sabe expresar, además, el giro que se quería dar a la Universidad, transformándola en la universidad de la cristiandad y del imperio, asumiendo e integrando lo mejor del humanismo, tal como en estos años se estaba viviendo en Roma, París y, ahora, en Salamanca. Con Pérez de Oliva aparece, también, lo lejos que nos si- 
tuamos no sólo de la filosofía y de la Universidad del XV sino de su talante. Aparecen otras actitudes, se hace otra filosofía, no al modo escolástico sino que nos situamos en el mundo, empeñados en su transformación al servicio del hombre y ante la expectación de lo nuevo.

Pérez de Oliva había nacido en Córdoba ${ }^{1}$, hacia 1494. Estudiaría primero en Salamanca, luego en Alcalá. Después marcharía a París, a la Sorbona y de aquí a Roma. En 1519 vuelve a París, en donde leyó diversas lecciones, entre ellas las Éticas de Aristóteles, y se graduó de licenciado y de maestro en Artes. Hacia 1524 regresa a España, y ya desde el curso 1524-25 parece que se inicia su vinculación con la Universidad de Salamanca y que va pasando por las cátedras de filosofía natural, moral, hasta obtener en 1530 la cátedra de teología nominal de Durando o de Gregorio de Rímini, tras haber perdido unos meses antes la de filosofía moral, que la obtuvo Alonso de Córdoba.

Sería rector de la Universidad de Salamanca del 12 de Marzo hasta expirar su mandato el 10 de Noviembre del mismo año. Y estuvo muy vinculado con todas las obras que en estos momentos se estaban llevando a cabo en la Universidad, así como con el Arzobispo Fonseca y su Colegio de Salamanca, del que además de ser colegial fundador sería rector desde el 17 de Octubre de 1530 hasta su muerte el 3 de Agosto de 1531.

De entre sus obras, destaco las siguientes: Razonamiento... sobre la navegación del rio Guadalquivir (1524), Historia de la inuención de las Yndias $(1528)^{2}$, Diálogo de la dignidad del hombre (1528), Diálogo del uso de las riquezas (1528), Amphitrión (1525), La venganza de Agamenón (1528), Cosmografia nveva, De Magnete, y De Lumine et Specie ${ }^{3}$.

De Pérez de Oliva quiero destacar tres aspectos, relacionados con las tres partes que tendrá mi exposición. El primero tiene que ver con su filosofía de la historia y su concepción de la fortuna, y me centraré en el Razonamiento... sobre la navegación del río Guadalquivir e Historia de la inuención de las Yndias, para mostrar esa mudanza en la imago mundi y esa necesaria modificación de la imagen del hombre y de la ciencia. El segundo está relacionado con su dedicación a los temas de arquitectura y el tercero, como tercera parte, a través del Diálogo de la dignidad del hombre, se centra en el nuevo relato e imagen del hombre y de la ciencia, que construye Pérez de Oliva, desde esa bella metáfora, vihuela templada, que hace dulce armonía, y que constituye el título de mi trabajo.

\section{FILOSOFÍA Y CIENCIA PARA UNA FILOSOFÍA DE LA HISTORIA.}

Su filosofía de la historia y su concepción sobre la ciencia aparece recogido principalmente en el Razonamiento que hizo el Maestro Fernán Pérez de Oliva en el Ayuntamiento de Córdoba, sobre la navegación del río Guadalquivir, y se proyecta, también, en la Historia de la inuención de las Yndias ${ }^{4}$.

1 Sobre Pérez de Oliva, véanse mis estudios, «Pérez de Oliva: reconstrucción biográfica», en Fernán Pérez de Oliva, Cosmografia nveva, Ediciones de la Universidad de Salamanca, Salamanca 1985, 27-68; Estatutos de la Universidad de Salamanca, 1529. Mandato de Pérez de Oliva, Rector, Ediciones de la Universidad de Salamanca, Salamanca 1984.

2 Pérez de Oliva, F., Historia de la inuención de las Yndias, estudio, edición y notas de José Juan Arrom, Publicaciones del Instituo Caro y Cuervo, Bogotá 1965.

3 Tengo delante, entre otras, Obras del Maestro Fernán Pérez de Oliva, natural de Córdoba, Rector que fue de la Universidad de Salamanca y Catedrático de Teología en ella; y juntamente quince discursos sobre diversas materias por su sobrino el celebre Ambrosio de Morales, Cronista del Catolico Rey D. Felipe, Córdoba 1586; Madrid $\left(2^{\mathrm{a}}\right) 1787,2$ vols.

4 Véase mi estudio, «Fortuna y filosofía de la historia en el Renacimiento. El impacto del Descubrimiento de Américas, en Actas del Simposio Filosofia y Ciencia en el Renacimiento, Universidad de Santiago de Compostela, 1988, 261-272. Así mismo, Carriazo Rubio, J.L., «Fernán Pérez de Oliva y el proyecto de navegación del Guadalquivir: Teoría y práctica del humanismo», en Gómez Canseco, L. (ed.), Anatomia del Humanismo: Benito Arias 
No voy a señalar, porque son múltiples las causas y objeto de atentos trabajos, cómo desde la Visión deleytable de Alfonso de la Torre y de la de Lope de Barrientos De caso y fortuna, hasta llegar a Nebrija y, ahora, a Pérez de Oliva, se va produciendo un giro tan sorprendente en la concepción del saber y en las cosmovisiones que los saberes proyectan, que bien se podría decir que estamos ante unos nuevos tiempos y unas actitudes nuevas.

Varias son las líneas de fuerza, que podrían explicar esta coyuntura, pero destaco de modo especial, la influencia del nominalismo como mentalidad generadora de nuevas visiones; la renovación y revalorización que progresivamente van adquiriendo y experimentando las Universidades en el conjunto de Europa, y en concreto aquí en Salamanca, sobre todo las Facultades de Artes, tanto en las disciplinas del trivium y del quadrivium, pero llenándolas de nuevos disciplinas, contenidos y tradiciones, como ocurría, por ejemplo, en la cátedra de matemáticas, a través de la aritmética, geometría, astrología, perspectiva y cosmografía. A esto añadiría el que todos los esfuerzos tendentes a clarificar el problema teórico de la redondez de la tierra habían dado un resultado experimental satisfactorio, culminando con el descubrimiento de América y la exitosa expedición alrededor del mundo de Juan Sebastián Elcano y Magallanes.

Este giro tan sorprendente en la concepción del mundo y del saber va a quedar reflejado también en la concepción que sobre la fortuna y la filosofía de la historia ofrecerá Pérez de Oliva, que se había formado, tal como he apuntado, en las universidades de Salamanca, Alcalá, París y Roma, impregnándose de las corrientes y tradiciones que, sobre todo, en estas últimas se cultivaban, en concreto la clásico-humanista de Roma y la lógico-científica de París. $\mathrm{Si}$ en la obra de Alfonso de la Torre la fortuna era el resultado de una cosmovisión teológica en cuyo centro la Bondad y Providencia divina desempañaban un papel primordial, ofreciendo o no resultados fortunados al hombre dentro de un horizonte de salvación; y si en Lope de Barrientos el hombre podía tender a originar la fortuna y a desvelar su advenimiento desde una perspectiva aristotélico-tomista, ahora, en Pérez de Oliva la fortuna no sólo es decididamente del hombre, sino que gracias a la acción y empeño de éste, la humanidad ha iniciado, o al menos a España ya le ha correspondido una nueva época histórica, la era de la fortuna. Esta se ha hecho presente, ahora, y está llamando insistentemente a las puertas de los corazones esforzados.

En el Razonamiento aparece Pérez de Oliva con una conciencia muy clara acerca de los nuevos tiempos que se habían inaugurado y de la responsabilidad que sobre todos pesaba. Por ello, hará en él una llamada a aceptar e impulsar dicha nueva época con la ciencia y con todos aquellos instrumentos científicos que pudieran ayudar a posibilitar el progreso y el bienestar de todos los hombres.

Desde esta perspectiva Pérez de Oliva reconstruirá la historia de los pueblos y sus destinos, y en concreto el de España, elaborando una filosofía de la historia, que señalaba cómo esta dedicación y cultivo de la ciencia, tanto en su vertiente teórica como experimental, habían dado a luz una nueva época en la historia, la de la fortuna, en cuyos afanes España se debía desvelar para guardarla y no dejarla escapar, máxime, ahora, bajo la guía del Emperador Carlos.

Para Pérez de Oliva dos factores han contribuido decisivamente a esta mudanza de los tiempos: la ciencia y la acción del hombre. Y desde esta respuesta tratará de definir la fortuna y de establecer las bases para una nueva filosofía de la historia, e incluso, teoría política.

Por eso, lo que se percibe desde esta perspectiva en este Razonamiento es la impresión tan honda y exultante que había causado en Pérez de Oliva la vuelta al mundo que hacía dos años, que se había realizado, así como los descubrimientos y realizaciones americanas. Eran para nuestro autor la prueba de cómo esa conjunción entre ciencia y acción del hombre producían mudanza de los tiempos y de las concepciones del mundo. Y era la fortuna de España. 
La fortuna, tal como aparece definida y señalada a través de diversos lugares del Razonamiento, significa acción científica del hombre, esto es, resultado de esa acción del hombre que sabe acompañarse de la ciencia. No encierra en sí entidad ni causalidad alguna, expresa más bien la acción del hombre en sus resultados, tal como se perciben desde los niveles de aspiración del ser humano. Por ello, la fortuna, en cuanto expresión de la acción del hombre en sus aspiraciones, significa prosperidad, abundancia, engrandecimiento, bienestar, fama, remedio de la adversidad, mejoramiento, riqueza, gloria, éxito, triunfo, cosas ilustres, poderío, señorío y grandeza. Esa acción del hombre debe ser inseparable de la ciencia y dice relación a un ideal de vida, que supone para alcanzar los bienes que se procuran: decisión, coraje, arrojo, esfuerzo, empeño, riesgo, sufrimiento, trabajo, emulación, constancia, mirada de futuro, ruptura con lo viejo y aceptación de lo nuevo, cosmopolitismo, dedicación de la riqueza a la ciencia, experimentación, dificultades, solicitud, abandono del ocio, del vicio, de la envidia, murmuraciones, discordias, juegos, hurtos, corrompimientos, persecuciones de las vírgenes, corrompimiento de los matrimonios y otros vicios semejantes. Eran, en definitiva, los nuevos valores y afanes del mundo moderno.

Con lo cual tenemos, tal como de otra manera lo había propuesto, manuscrito todavía, Maquiavelo en El príncipe, la imagen renacentista no ya de la fortuna, sino del varón y de los pueblos que son y que quieren ser fortunados, o mejor, del que puede aspirar y esperar de los bienes que esa acción procura si cabe cultivar y adecuarse a ese programa y exigencias de acción y de vida, que como ideal se ofrece. $Y$ ésta es, a mi modo de ver, la óptica que preside y que se extiende a la Historia de la inuención de las Yndias.

\section{UN UNIVERSO SIMBÓLICO CONCERTADO}

El segundo aspecto, que quiero señalar de Pérez de Oliva, es su relación con las obras que se estaban acometiendo en Salamanca y, en concreto, con las que sabemos que entendía, en las de la Universidad y en las del Colegio Mayor del Arzobispo Fonseca.

En Pérez de Oliva hay una idea humanista de la arquitectura, ésta debía tender a crear espacios simbólicos que expresaran la nueva época, el universo, en el cual nos encontrábamos y las tareas a las cuales éramos llamados.

El viejo edificio de la. Universidad va experimentando en los últimos años del XV y en estos primeros del XVI una profunda transformación, y se van a acometer las obras de ampliación, en lo que van a ser las Escuelas Menores. La fachada de las Escuelas Mayores, acabada hacia 1529, se había adosado a la fachada del edificio gótico, y a modo de telón o estandarte ocultaba la antigua portada del siglo XV, casi hacía olvidar la antigua Universidad Pontificia y los viejos tiempos. La nueva fachada era el estandarte del Imperio, de la nueva era que enraizada en la Monarquía, había que seguir. Y la mano de Pérez de Oliva parece estar presente en los programas alegóricos tanto de la fachada de la Universidad, como en la escalera y librería nueva del Estudio, así como en las Escuelas Menores. En ellos se expresaba el nuevo universo simbólico en el cual se situaba la Universidad bajo la impronta de la Monarquía y del Emperador, Carlos V.

La Universidad, en ese nuevo universo simbólico, era una institución que asumía su fortuna histórica y esa llamada a perseverar y continuar en ella bajo la guía del Emperador, tendiendo a hacerla extensiva a todo el orbe.

Espacio simbólico y alegórico, que se creaba y arrancaba ante la fachada de la Universidad. Se nos situaba en los nuevos tiempos y nos obligaba al igual que a Polifilo ${ }^{5}$, tras su des-

5 Colonna, F., El sueño de Polifilo, traducción literal y directa del original aldino, introducción, comentarios y notas de Pilar Pedraza, Murcia 1981, 2 vols. Esta obra se había publicado en Venecia 1499 con el título Poliphili 
pertar en sueño, a contemplar la fachada y los blasones desplegados de la domus aurea o domus romana ${ }^{6}$, que mostraban la naturaleza y condición de su dueño, y a preguntarnos por la puerta a la que debíamos llamar. La clásica imagen del hombre en la encrucijada, ¿Quod vitae sectabor iter? ¿Qué camino he de tomar? ¿A dónde nos podría conducir cada una de esas dos caras de esta puerta bifronte?

La fachada de la Universidad lucía un programa heráldico, que tejía todo un conjunto de relaciones institucionales con la Monarquía, que arrancaba con los Reyes Católicos y que en línea ascendente, en su cuerpo central, se detenía en un gran escudo de España con las armas de Carlos I, rey de España y Emperador de Alemania ${ }^{7}$, y culminaba con una recreación del sello de la Universidad sin ninguna alusión específica a un pontífice sino más bien a la dependencia pontificia de la Universidad. A cada lado del pontífice hay recuadros entre medallones cuyo tema, en el izquierdo es una Venus apoyada en un fuste quebrado, los dos medallones y sus emblemas que significan las virtudes de la justicia y de la templanza, siendo, respectiva y probablemente los que aparecen en los medallones, Trajano o Alejandro y Cesar. En el lado opuesto, y con igual disposición, el recuadro muestra la figura de Hércules apoyado en la clava, mientras los medallones y emblemas representan, también probable y respectivamente, a la izquierda del espectador, la prudencia y en el medallón, Marco Aurelio, y a la derecha la fortaleza, encarnada en Escipión.

Pero además de esto, contemplando la fachada de arriba abajo bien pudiera ser que se estuviera expresando el rango y jerarquía de los saberes, de las virtudes, de los estados de los hombres, especialmente «del estado de los hombres letrados» y «de los que goviernan» ${ }^{8}$.

De este modo, se fundía la Universidad con la Monarquía, las virtudes y los saberes al servicio de proyecto político. Con ello se ponía de manifiesto «la dignidad de la enciclopedia, es decir, del saber que custodiaba la universidad y que se encontraba al servicio de la corona ${ }^{9}$. Y esto es lo que parece decir Antonio a Aurelio en el Diálogo de la dignidad del hombre de

Hypnerotomachia, y es junto con las de Brant, S., Das Narrenschift, (1 $\left.1^{\mathrm{a}}\right) 1494$, Stultifera navis, J. Bergmann von Olpe, Basileae 1497, y las de Erasmo de Rotterdarn, Enchiridion militis christiani, Louvain 1503, Moria encomium, Paris 1511, Institutio principis christiani, Basileae 1516, Querela pacis, Basileae1517, son las obras, digo, que sirven para crear este universo y espacio simbólico: encrucijada, doble puerta, morada, camino, advertencias, sabiduría, república cristiana. Trataré de exponerlo ajustado a la brevedad del caso. Citaré de Brant, S., La nave de los necios, Edición de Antonio Regales Serna, Akal Ediciones, Madrid 1998. De Erasmo de Rotterdam, Enquiridion. Manual del caballero cristiano, Introducción, traducción y notas de Pedro Rodríguez Santidrián, BAC, Madrid 1995, y Elogio de la locura, Introducción, traducción y notas de Pedro Rodríguez Santidrián, Alianza Editorial, Madrid 1998.

6 Pereda, F., La arquitectura elocuente. El edificio de la Universidad de Salamanca bajo el reinado de Carlos V, Sociedad Estatal para la Conmemoración de los Centenarios de Felipe II y Carlos V, Madrid 2000. Gabaudan, P., El mito imperial. Programa iconografico de la Universidad de Salamanca, Junta de Castilla y León, Consejería de Educación y Cultura, Valladolid 1998.

7 Cf. Alvarez Villar, J., La Universidad de Salamanca, III. Arte y tradiciones, Ediciones de la Universidad de Salamanca, Salamanca 1990, 55, aunque Pereda, F, La arquitectura, matizando, apunta: «Por tanto, deberemos concluir que ninguna de las insignias del escudo central de la fachada permite reconocerlo en sentido estricto como el escudo del Emperador, o no sólo del suyo, como veremos (236)... Nuestra conclusión, por tanto, es que el escudo de la fachada de la Universidad no es tan sólo el del Emperador, sino el de los reyes de España, Don Carlos y su madre, doña Juana. El hecho de haber evitado todo mote o emblema personal del Emperador a excepción del Toisón, que ya se había vinculado a la monarquía española así parece demostrarlo», 237-38. Posiblemente, desde la interpretación de Felipe Pereda, tal como concluye: «El claustro eligió una formula heráldica en la que el peso caía sobre el equilibrio monárquico entre la corona española y el imperio. La situación será muy otra cuando algunos años más tarde se realice la fachada de las Escuelas Menores donde si bien tomando la misma disposición, ahora ya todas y cada una de las tres águilas, tanto la que cobija el escudo central como las que lo flanquean, son águilas bicéfalas con coronas imperiales y, por supuesto, con el añadido de las columnas y el mote 'PLUS ULTRA'», 239.

8 Fernán Pérez de Oliva, Diálogo de la dignidad del hombre, Edición de María Luisa Cerrón Puga, Cátedra, Madrid 1995, 156 y 161. Citaré por esta edición.

9 Pereda, F., La arquitectura elocuente, 296. 
Pérez de Oliva: «Agora el orden por donde tú, Aurelio, me guiaste, requiere que diga del estado de los hombres letrados; do primero escucha lo que dixo Salomón en sus Proverbios: Bienaventurado es el que halló sabiduría y abunda de prudencia; mejor es su ganancia que la de oro y plata, y todas las cosas excede que se pueden desear. ¡Gran cosa es, Aurelio, la sabiduría, la cual nos muestra todo el mundo, y nos mete a lo secreto de las cosas, y nos lleva a veer a Dios, y nos da habla con Él y conversación, y nos muestra las sendas de la vida! Ésta nos da en el ánimo templança; ésta alumbra el entendimiento, concierta la voluntad, ordena el mundo, y muestra a cada uno el oficio de su estado; ésta es reina y señora de todas las virtudes; ésta enseña la justicia y tiempla la fortaleza; por ella reinan los reyes y los príncipes goviernan; y ella halló las leyes con que se rigen los hombres» ${ }^{10}$. Era centrar el cultivo de los saberes y de las virtudes en la sabiduría al servicio de la Monarquía para afrontar los nuevos tiempos.

Contemplando así tanta maravilla, ¿podía caber duda acerca del camino a tomar y luego seguir?

La advertencia cifrada y sonora de la rana de la fachada nos lo recordaba permanentemente. La evocación era bien clara, venía de la mano de Erasmo en el Elogio de la locura: «Una vez más me aturden con su croar las ranas del pórtico... ¿Qué es estar loco más que haber perdido la cabeza?». No seguir la verdadera sabiduría y enredarse en falsos sofismas como lo hacen los dialécticos ${ }^{11}$. Y era ayudarnos a recordar las imágenes y texto del grabado 27 de $\mathrm{La}$ nave de los necios de Sebastián Brant (1457-1521): «Quien no estudia la verdadera ciencia, el mismo se toca los cascabeles y es conducido en la cuerda de los necios»; para en el comentario señalar: «A los estudiantes tampoco los paso por alto. Tienen de antemano la capa como premio, y, a poco que toquen ésta, la capucha sigue detrás; pues, cuando deberían estudiar de firme, prefieren ir a golfear. La juventud tiene en muy poca estima toda ciencia; ahora prefieren aprender sólo lo que es inútil e infecundo. Lo mismo se echa en falta también en los profesores, pues no respetan la verdadera ciencia y sólo prestan atención a una inútil charlatanería; si era de día o de noche, si un hombre ha fabricado un burro, si corre Sortes (Sócrates) o Platón. Tal enseñanza es lo que hoy ofrecen las escuelas. ¿No son necios y tontos de capirote los que noche y día andan por ahí con esas cosas y se atormentan ellos mismos y atormentan a los demás? No respetan ninguna ciencia mejor. Por eso Orígenes dice de ellos que son las ranas y las langostas que devastaron Egipto» ${ }^{12}$. ¡Qué advertencia se nos hacía! Éramos llamados no a la palabrería sofística, y sí al cultivo de la verdadera sabiduría.

La fachada en doble puerta nos invitaba a hacer el camino, a entrar y visitar cada una de las moradas de los distintos saberes de la domus aurea, del palacio de la sabiduría. La experiencia del camino nos transformaría en caballeros de la sabiduría al servicio de la paz y de la concordia. Viaje y camino, que se nos mostraba como una nueva lucha de amor en sueño, y para no ser arrastrados como Polifilo y salir victoriosos como Hércules se nos iba a dar un manual de imágenes precisas.

La escalera era ese camino ${ }^{13}$, que era manual y método que se tenía a la mano, era $E n$ chiridion o Manual del caballero cristiano. Era la nueva filosofía humanistà de Erasmo de Rotterdam que se expresaba en Salamanca. Era el Elogio de la locura, elogio de la verdadera sabiduría, eran los grabados, la música festiva de los que iban ad Narragoniam en La nave de los necios de Brant. ¡Cuántas veces aparece el término camino en el Enchiridion! Las imágenes del peregrino, del caminante, de la locura, invectivas contra la fascinación de los sentidos

10 Fernán Pérez de Oliva, Dialogo, 156-57.

11 Erasmo de Rotterdam, Elogio de la locura, XXXVIII, pág. 83.

12 Brant, S., La nave de los necios, 126-27.

13. Desde otra perspectiva, aunque algunos aspectos parcialmente podrían ser complementarios, cf., Cortés Vázquez, L., Ad summum caeli. El programa humanista de la escalera de la Universidad de Salamanca, Ediciones de la Universidad de Salamanca, Salamanca 1984. 
contra la lujuria, el perro de la fábula de Esopo ${ }^{14}$...; la imagen de la abeja que liba la flor, el veneno ${ }^{15}$, la sirena ${ }^{16}$, no Eros encadenado sino Proteo ${ }^{17}$ encadenado, los caballeros tras la elección y tras haber encadenado al Proteo que siempre llevamos dentro, los toros asaeteados por los caballeros como réplica al toro del Sueño de Polifilo, que se llevó a la ninfa Polia montada sobre él. Era, en fin, la Educación del príncipe cristiano y la Querela pacis (1517), la imagen de la concordia y de la vera amicitia, el sueño de la restauración de la christianitas, de la república cristiana.

En la escalera, y dispuestos a hacer el camino se encuentran Pérez de Oliva, el Arzobispo Fonseca, Erasmo y el Emperador. ¿Quod vitae sectabor iter? No cabía duda de que se había inaugurado una nueva era. El nuevo universo simbólico así lo expresaba. La llegada al rectorado de Pérez de Oliva, apalancado por el Arzobispo Fonseca y su Colegio Mayor, y por la política del Emperador, así como los Estatutos de la Universidad de Salamanca de 1529, completarían esta elección ${ }^{18}$. Pero los acontecimientos que se sucederían a partir de 1536 y tras la muerte de Erasmo, harían variar esta perspectiva y ensoñación, y un repliegue por parte de la Universidad de Salamanca hacia Aristóteles y Santo Tomás como doctrina segura y salvadora.

\section{UNA IMAGEN DEL HOMBRE Y DE LA CIENCIA}

Tal como he indicado, me voy a referir en esta tercera parte, a la presentación que Pérez de Oliva va a hacer del hombre, fijándome, principalmente en su Diálogo de la dignidad del hombre (1528).

En torno a este Diálogo se han escrito ya muchas páginas y se han destacado aspectos importantes ${ }^{19}$. Mi intención; en este breve trabajo, no es volver sólo a recrear la bella imagen, que nos presenta Pérez de Oliva, sino mostrar cómo repiensa la imagen del hombre que se recibe de la antiguiedad y cómo la hace renacer a una dimensión nueva. Asistimos a lo que es una ejemplificación de lo que es el renasci, o si se quiere, estamos ante la creación de una imagen de un hombre nuevo, inclusive de una teoría del hombre, a la medida del mundo moderno, ajustada a las necesidades que había que afrontar.

La perspectiva de Pérez de Oliva enriquecía e iba más allá de la consideración que podía hacerse de éste desde el ente finito o desde los comentarios al De anima. Se situaba en esa nueva era mesiánica y en ese optimismo que rodeaba la acción política del Emperador. Y expresaba no tanto, o tal vez más, la grandeza del hombre cuanto la confianza en el hombre para poder encarar los desafíos de los nuevos tiempos. Es la imagen del hombre engrandecido, que sabe de su dignidad, de sus poderes y limitaciones, y de su tarea de transformar el mundo.

14 Erasmo de Rotterdàm, Enquiridion. Manual del caballero cristiano, 195: «Pues ¿qué más necio y vergonzoso que perder las cosas reales por ir tras las ilusiones, que es precisamente lo que nos hace reír de aquel perro de la fábula de Esopo?».

15 Ibidem, 79: «Si escoges lo mejor y cual abeja que va volando por todos los huertecillos de los antiguos, dejas el veneno y chupas solamente el jugo sano y generoso, te sentirás no menos armado para esa vida común que llaman 'ética'».

16 Ibidem, 246-47: «Huye cauta y diligentemente de todas las tentaciones de la carne. Conviene que observes también esta regla en todas las demás tentaciones, porque quien ama el peligro merece caer en él. Pero de esta clase de tentaciones —como de las sirenas - nadie se libra más que los que se alejan de ellas».

17 Ibidem, 109: «Mientras tanto, y cuando tu alma arda en pasiones violentas, tú has de apremiar, urgir, amenazar y atar a este tu Proteo con fuertes cadenas, aun cuando 'se transforme en toda suerte de cosas prodigiosas: fuego, fiera horrible, agua fluente' (Virgilio, Geórgicas, I, 145-46), hasta que vuelva a su forma nativas.

18 Este es el núcleo de la problemática que se vive en estos años y que se expresa de muy distintas maneras. No tener en cuenta esta conjunción de elementos y expresiones, es ponerse a gallear inútilmente para detener el curso del sol o para no ver la claridad que éste irradia.

19 Cf., Rico, F., El pequeño mundo del hombre, Alianza Editorial, Madrid 1986. 
Es el hombre que se halla revestido de su propia dignitas y que quiere llenar el mundo de esta su grandeza y dulce armonía, porque sabe que en la medida en que engrandece al hombre, en esa misma medida está, en definitiva, engrandeciendo a su Creador y a la tarea que éste le tenía asignada. ¡Nada de las cicaterías de las Escuelas! ¡Nada de incidir en la caída! Situémonos en la mirada del Creador, en su obra y en la empresa hermosa que asignaba al hombre: humanizar, divinizar la tierra entera, llenarla de perfume divino. jGran cosa es el hombre y admirable!

El discurso de la antigüedad clásica, en boca de Aurelio o del emperador Marco Aurelio que hemos visto esculpido en la fachada, pintará, en la primera parte, la imagen del hombre como «cosa vana y miserable», apelará a su condición miserable, a su razón contradictoria, filtrada a través del escepticismo: «Y también porque él, de suyo, no es muy cierto en el razonar y en el entender, unas vezes siente uno y otras vezes el mesmo siente lo contrario, siempre con dubda y con temor de afirmarse en ninguna cosa; de do nasce, como manifiesto veemos, tanta diversidad de opiniones de los hombres, que entre sí son diversos. Por lo cual yo munchas vezes me duelo de nuestra suerte, porque teniendo nosotros en sola la verdad el socorro de la vida, tenemos para buscarlas tan flaco entendimiento que, si por ventura puede el hombre alguna vez alcançar una verdad, mientras la procura, se le ofresce necesidad de otras mil que no puede seguir» ${ }^{20}$.

El hombre como ser tensionado entre razón y apetito natural, entre Venus y Hércules de la fachada: «¿Qué cosa puede ser más aborrescible que el hombre?», cuando es ablandado y distraído por la sensualidad con gula y pereza, cuando «la templanza se resfría», cuando la voluntad de la razón se aparta, y otros vicios aparecen como «la sobervia, cobdicia, invidia, enemistad y otros que hay semejantes; de do nascen las guerras, las muertes, las gravísimas perturbaciones en que traen los hombres al mundo» 21 .

¡Cuantos afanes! Es el Sísifo que dixeron los poetas, «que tantas vezes sube una piedra a la cumbre de un monte infernal, tantas vezes se le cae y torna al trabajo» ${ }^{22}$. ¡Cuanta melancolía en la mirada! Los distintos estados, profesiones, empleos, oficios, «no son sino diversos modos de penar,... Y así andan los hombres, atónitos, errados, buscando su contentamiento donde no pueden hallarlo. $Y$ entre tanto se les pasa el tiempo de la vida, y los lleva a la muerte con pasos acelerados, sin sentido» ${ }^{23}$.

¿Y la fama? ¡La fama!, «vana consoladora de la brevedad de nuestra vida». ¿A qué me vienes con la fama? «¿Qué aprovecha a los huesos sepultados la gran fama de los hechos?.. Los cuerpos en la sepultura no son diferentes de las piedras que los cubren: allí yazen en tinieblas, libres de bien, y de mal, do nada se les da que ande el nombre bolando con aires de la fama» ${ }^{24}$. Todo esto se va en humo, el tiempo lo borra todo. Ahí quedan el hombre y su fama, «enterrado en olvido perdurable» 25 .

Esta era la imagen que Aurelio, sobre todo desde Marco Aurelio, nos traía del hombre. Este era el hombre que había que renacer y que restaurar para los nuevos tiempos, para el mundo moderno, para el sueño imperial, desde una sabiduría que ofreciera una mejor y más completa imagen del hombre. «Hasta aquí, Dinarco, me ha parecido dezir del hombre; ahora yo lo dexo a él y su fama enterrados en olvido perdurable. Yo no sé con qué razones tú, Antonio, podrás resucitarlo. Dale vida, si pudieres, y consuelo contra tantos males como has oído, que si 
tú así lo hizieres, yo seré vencido de buena gana, pues tu victoria será gloria para mí, que me veré constituido en más excelente estado que pensava» ${ }^{26}$.

Pero, Pérez de Oliva con este su Diálogo no sólo asumía esta tarea de repensar la antiguiedad clásica, sino que, de otra manera, estaba dando una nueva legitimidad al hacer histórico filosófico que a través de este mismo Diálogo estaba practicando. Además, no utilizaba la filosofía escolástica para repensar al hombre, sino que empleaba un género y un método distinto: el diálogo y, éste, en castellano. De otra parte, y me parece todavía más importante, se establecía una línea de continuidad entre la antigiiedad clásica, Roma, sin mediación escolástico-medieval, y la nueva época con su nueva filosofía. Fenómeno muy similar al que se estaba ensayando en el campo político, entre Roma y el Imperio, o en las distintas legitimaciones nacionales, o los proyectos de una nueva respublica christiana, a través de toda una serie de recursos simbólicos. El recurso a la antigüedad clásica, al igual que al mito del Imperio Romano, daba legitimidad y hondura histórica para poder distanciarse de la escolástica, esto es, de lo antiguo, y emprender una filosofía nueva, adaptada a las urgencias de los tiempos, las del Imperio.

Por eso, la respuesta, que Pérez de Oliva dará a Aurelio, será una respuesta que sabe asumir el bien trabado discurso de Aurelio, en el que pocos resquicios había para el optimismo. Había que variar la perspectiva y transfigurar la imagen y el destino del hombre. Había que crear de nuevo al hombre, asistir a su nuevo nacimiento y a su nuevo destino. Había que construir el relato de la nueva creación. Creación del hombre corpóreo, hecho de carne y hueso, no el ente finito de la especulación escolástica, sino del hombre entero que nos venía de la antigüedad clásica a través de Marco Aurelio.

Comienza así Antonio: «Considerando, señores, la composición del hombre — de quien oy he de decir-, me parece que tengo delante los ojos la más admirable obra de cuantas Dios ha hecho, donde veo no solamente la excelencia de su saber más representada que en la gran fabrica del cielo, ni en la fuerça de los elementos, ni en todo el orden que tiene el universo; mas veo también como en espejo claro el mismo ser de Dios y los altos secretos de su trinidad» ${ }^{27}$. Recogerá los lugares, ya conocidos en Pico de la Mirándola, de Hermes Trismegisto, exaltando la grandeza y potencia del hombre, pero irá en derecho al relato de la creación del libro del Génesis, 1,26: «Hagamos el hombre a nuestra imagen y semejança», deteniéndose en cómo Dios dobló la palabra cuando dijo «imagen y semejança» para extraer toda la riqueza encerrada en el hombre devenido en ese acto creador.

La grandeza del hombre está en ser hechura y semejanza de Dios, puesto para ordenar el mundo y para que a través de las obras del hombre se supiera quién había sido su hacedor: «Los antiguos fundadores de los pueblos grandes, después de hecho el edificio, mandavan poner su imagen esculpida en medio de la cibdad, para que por ella se conosciese el fundador; así Dios, después de hecha la gran fábrica del mundo, puso al hombre en la tierra, que es el medio dél, porque en tal imagen se pudiese conoscer quién lo havía fabricado" ${ }^{28}$. Por ello a través de esta tarea divina recibida adquiere pleno sentido la existencia.

Ver al hombre es contemplar el ser más bello de toda la creación. Su belleza recorre cada parte de su cuerpo entero, y en todas y cada una de sus partes resplandece una belleza singular. Y frente a la imagen que nos había dado la antigüedad clásica: «puedes comprender, Aurelio, que no es el hombre desamparado de quien el mundo gobierna, como tú dixiste; mas antes bastecido más que otro animal alguno, pues le fueron dados entendimiento y manos para esto bastantes, y todas las cosas en abundancia de que se mantuviese» ${ }^{29}$. El hombre es, además, un 
ser dotado de libertad, «tiene libertad de ser lo que quiere», tiene entendimiento y voluntad, y está dispuesto, también, a aspirar a la verdadera sabiduría, poniendo rumbo a ella, pues «el camino a ella es el deseo de alcanzarla», y «ésta nos muestra todo el mundo, y nos mete a lo secreto de las cosas,... ésta alumbra el entendimiento, concierta la voluntad, ordena al mundo, y muestra a cada uno el oficio de su estado» ${ }^{30}$, para que las cosas que el hombre «viera con los ojos del entendimiento» pudiera «alcançarlas con las manos corporales».

Por ello, el hombre es o debería ser «como la vihuela templada, que haze dulce armonía» ${ }^{31}$. Esta bella imagen, es la que permite a Pérez de Oliva presentar al hombre afrontando y dispuesto a afrontar, produciendo dulce armonía, los retos del mundo moderno, y dejando en el olvido viejas imágenes y temores: «El cual (hombre) para mí es cosa admirable cuando considero que aunque estemos aquí, — como tú dixiste — en la heż del mundo, andamos con él por todas partes: rodeamos la tierra, medimos las aguas, subimos al cielo, veemos su grandeza, contamos sus movimientos y no paramos hasta Dios, el cual no se nos esconde. Ninguna cosa ay tan encubierta, ninguna ay tan apartada, ninguna ay puesta en tantas tinieblas, do no entre la vista del entendimiento humano para ir a todos los secretos del mundo» ${ }^{32}$.

Somos la vihuela templada que, concertando la ciencia y la acción del hombre, hace dulce armonía, que sabe transformar el mundo en un locus amoenus, como morada deleitosa de paz para el hombre, con «prados floridos» y «aguas claras que por medio corren», con «arboledas llenas de ruiseñores» y otras aves, que «con su canto nos deleitan ${ }^{33}$. Y tal como lo describirá, también, Fray Luis de León, unos años más tarde en De los nombres de Cristo, «los campos de flor eterna vestidos, y los mineros de las aguas bivas, y los montes verdaderamente preñados de mil bienes altísimos, y los sombríos y repuestos valles, y los bosques de la frescura, adonde, esentos de toda injuria, gloriosamente florecen la haya y la oliva y el lináloe, con todos los demás árboles del incienso, en que reposan exércitos de aves en gloria y en música dulcísima que jamás ensordece» ${ }^{34}$.

Ese concierto entre sabiduría y vida, manos y entendimiento, entre filosofía y ciencia, es la que «como la vihuela templada, haze dulce armonía, y, cuando se destiempla, ofende los oídos». Y Fray Luis de León, en el nombre «Príncipe de la Paz», apuntará, «como la piedra que en el edificio está assentada en su devido lugar, o por dezir cosa más propia, como la cuerda en la música, devidamente templada en sí misma, haze música dulce con todas las demás cuerdas sin dissonar con ninguna, assí el ánimo concertado dentro de sí,... consuena con Dios y dize bien con los hombres y, teniendo paz consigo mismo, la tiene con los demás» ${ }^{35}$. Es por ello, que «si el hombre se tiempla con las leyes de virtud, no hay cosa más amable; más si se destiempla con los vicios, es aborrescible» ${ }^{36}$, teniendo en esto «libre poderío» para, dominando sus pasiones, alcanzar la verdadera fama y gloria que, al fin, será otorgada por Dios al hombre en su eterna bienaventuranza, y que culminará con la transfiguración de la imagen terrena de éste.

Y este era el discurso de Antonio frente al de Marco Aurelio, con el que se cierra este Diálogo. El discurso-programa del hombre nuevo para un mundo nuevo, que desde el hombre y la ciencia cabía construir.

31 Ibidem, 156.

32 Ibidem, 153.

33 Ibidem, 115 y 159.

34 Fray Luis de León, «Paston», De los nombres de Cristo, edición de Cristóbal Cuevas García, Cátedra, Ma$\operatorname{drid}\left(4^{\mathrm{a}}\right) 1984,225$.

35 Ibidem, 416-17.

36 Pérez de Oliva, F, Diálogo, 157-58. 


\section{CONCLUSIÓN}

A través de esta exposición, he pretendido mostrar la abundancia de contenidos y evocaciones, que arrastraba, y que suscita, esta bella imagen del hombre y de la ciencia, como la vihuela templada, que hace dulce armonía. Hemos visto, en la primera parte, como la filosofía, la ciencia y la acción del hombre se unían concertadas en una filosofía de la historia, que sabía dar al hombre el puesto de gran maestro y artífice de ese mundo nuevo, que exultante, en el Renacimiento surgía. En la segunda parte, hemos contemplado un universo simbólico conciliado, era el mundo ordenado y transformado en ajustado movimiento, que tendía a la vera amicitia, desde el concierto de las virtudes y los saberes. $Y$ en la tercera, disfrutando anticipadamente del mundo, transfigurado en locus amoenus, se nos ha acabado desvelando la riqueza de esa bella imagen, que inunda todo de dulce armonía.

Por ello, frente al croar de las ranas o el sonido de los cascabeles de la cuerda de los necios, ique suene la música de continuo!, la dulce armonía, que el hombre, ahora, nos podía ofrecer.

José Luis Fuertes Herreros

Universidad de Salamanca

Facultad de Filosofía

Campus «Miguel de Unamuno»

37007 Salamanca

jfuertes@usal.es 